\title{
FIRST RECORD OF CORTODERA FLAVIMANA (WALTL, 1838) (COLEOPTERA: CERAMBYCIDAE) IN CROATIA
}

\author{
Mladen Zadravec* \& Toni Koren
}

Association Hyla, Lipovac I no. 7, 10000 Zagreb, Croatia

\begin{abstract}
Zadravec, M. \& Koren, T.: First record of Cortodera flavimana (Waltl, 1838) (Coleoptera: Cerambycidae) in Croatia. Nat. Croat., Vol. 25, No. 2., 315-320, Zagreb, 2016.

Cortodera flavimana is a Pontic species which occurs from Austria and Hungary, through Serbia and south-eastern Europe and Turkey. It was not previously known from Croatia. Two specimens were found, one in Cerna (E Croatia, in 2008) and one in Okuje (NW Croatia, in 2013), raising the number of known Cortodera species in Croatia to five; the other being C. humeralis, C. femorata, C. holosericea and C. villosa. These records represent an expansion of the species' known range and indicate the possibility of new records, at least in Croatia, and the need for further research into longhorn beetles in the country.
\end{abstract}

Key words: longhorn beetles, Cerna, Okuje

Zadravec, M. \& Koren, T.: Prvi nalaz vrste Cortodera flavimana (Waltl, 1838) (Coleoptera: Cerambycidae) za Hrvatsku. Nat. Croat., Vol. 25, No. 2., 315-320, Zagreb, 2016.

Cortodera flavimana je pontijska vrsta, rasprostranjena od Austrije i Mađarske preko Srbije i jugoistočne Europe do Turske. Do sada nije bila zabilježena za Hrvatsku. Pronađena su dva primjerka, jedan kod Cerne (istočna Hrvatska, 2008. godine) i jedna kod Okuja (sjeverozapadna Hrvatska, 2013. godine), čime je broj poznatih vrsta roda Cortodera iz Hrvatske porastao na pet; ostale četiri su C. humeralis, $C$. femorata, $C$. holosericea i $C$. villosa. Ovi nalazi predstavljaju proširenje poznatog areala te vrste, ukazuju na mogućnost novih nalaza u budućnosti, barem iz Hrvatske, i ukazuju na potrebu daljnjeg istraživanja faune strizibuba Hrvatske.

Ključne riječi: strizibube, cvilidrete, Cerna, Okuje

\section{INTRODUCTION}

Longhorn beetles (Cerambycidae), with many large and/or conspicuous species, have always captivated the interest of entomologists. In recent years, there have been many advances regarding the knowledge of European longhorns: many faunistic papers covering specific regions were published, along with a plethora of new information about the biology, larval development and host plant preferences (BENSE, 1995; SAMA, 2002). Because of this they are regarded as the beginner group for both new amateur and professional coleopterists (BENSE, 1995). The larvae of many species develop in wood, with some being pests, attracting the attention of forestry workers. The larvae of others, especially in southern Europe, develop in herbaceous plants (BENSE, 1995). Adults of some species do not feed at all. Those that do eat either leaves and twigs, or the pollen and nectar of flowers (BENSE, 1995). The research, although sporadic, into Croatian Cerambycid fauna dates back to the first half of the $20^{\text {th }}$ century (Depoli, 1942; Müller, 1905,

\footnotetext{
* corresponding author: mladen.z123@gmail.com
} 
1906a, 1906b, 1906c). Most papers focused on the Mediterranean part of the country, a trend which has continued to this day (Demelt \& Schurman, 1964, 1966, 1973; Koren, 2010; Koren et al., 2010; Koren \& Perović, 2010; MiKšić, 1951; NovaK, 1952, 1964, 1970). The first comprehensive review of the Croatian Cerambycidae, as a part of the Yugoslavian cerambycid fauna, was given by Mikšıć (1963), followed by MiKšıć \& Georgijević (1971; 1973; 1985). According to them, there are at least 225 longhorn beetle species in Croatia. In the last decade, several new species were recorded for the first time for Croatia: Agapanthia viti Rapuzzi et Sama, 2012 (Kovács et al., 2012), Stenurella sennii Sama, 2002 (Rapuzzi et al., 2011), Leiopus linnei Wallin, Nylander et Kvamme, 2009 (Wallin et al. 2009), Callidiellum rufipenne (Motschulsky, 1862) (Łos \& Plewa, 2011) and Anoplophora chinensis (Forster, 1771) (VuKAdin, 2011; VuKAdIN \& Hrašovec, 2008, 2012), the latter two being classified as alien pests.

Longhorn beetles of the genus of Cortodera Mulsant, 1863 are small beetles, ranging from seven to $14 \mathrm{~mm}$ in length. Adults can be found from late April to July on flowers of various plants, e.g. Crataegus, Fraxinus, Plantago, Ranunculus, Paeonia, Chrysanthemum (Ilić \& Ćurčić, 2013; Mikšić \& Georgijević, 1971). At present, there are 14 species in Europe (DE Jong et al., 2014). Of those, three are most certainly present in Croatia: $C$. humeralis (Schaller, 1783), C. femorata (Fabricius, 1787), C. holosericea (Fabricius, 1801), while the occurrence of C. villosa Heyden, 1876 is listed as doubtful (Mıкšıć, 1963; MıкŠić \& Georgijević, 1971). A Pontic species, C. flavimana (Waltl, 1838), is also known from the region. In Europe, it occurs in Austria, Hungary, Serbia, Macedonia, Greece, Romania, Bulgaria, and Turkey (Adlbauer, 2001; Ilić \& Ćurčıć, 2013; Özdikmen, 2003; VukajLović \& ŽIvanović, 2015). Here we present the first findings of this species in Croatia.

\section{MATERIAL AND METHODS}

The longhorn beetles were collected by hand during visits to Cerna (SW of Vinkovci,

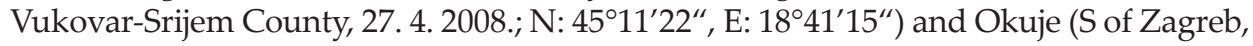

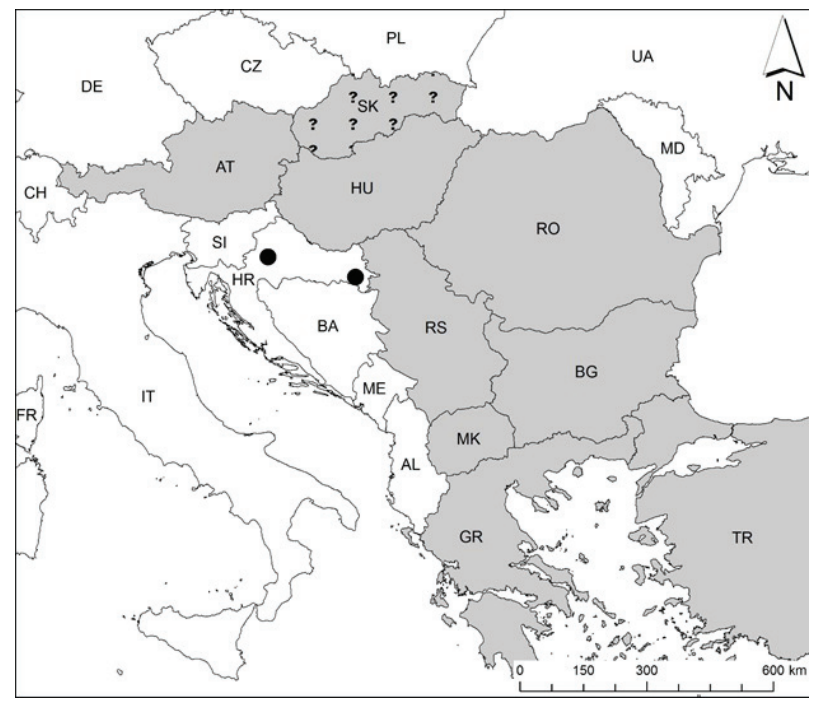

Fig. 1. Distribution of Cortodera flavimana in Europe (grey). ? - doubtful presence; $\bullet$ - new records. 


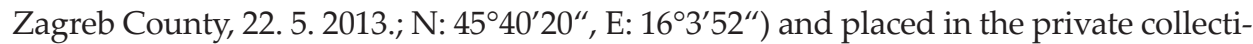
ons of the authors. They were identified using Bense (1995). Photos of the specimens were sent to P. Rapuzzi, who confirmed the identification.

\section{RESULTS AND DISCUSSION}

In total, two individuals of C. flavimana were collected, one per locality (Figures 1 and 2). C. flavimana can be easily distinguished from C. humeralis and C. femorata by the distinctly expanded last segment of the maxillary palp, while the dense semi-recumbent light yellow or golden pubescence on its head and pronotum distinguish it from C. villosa and C. holosericea (BENSE, 1995). Both individuals are from the continental part of Croatia, with the Cerna locality being only approximately $55 \mathrm{~km}$ from the closest finding of this species in Serbia. Both were found on a mosaic of wet grasslands with bushes and deciduous forest. Since those habitat combinations occur in other parts of north-western and eastern Croatia, especially between the new findings and the rest of the distribution range, and between the new records themselves, additional records from Croatia are to
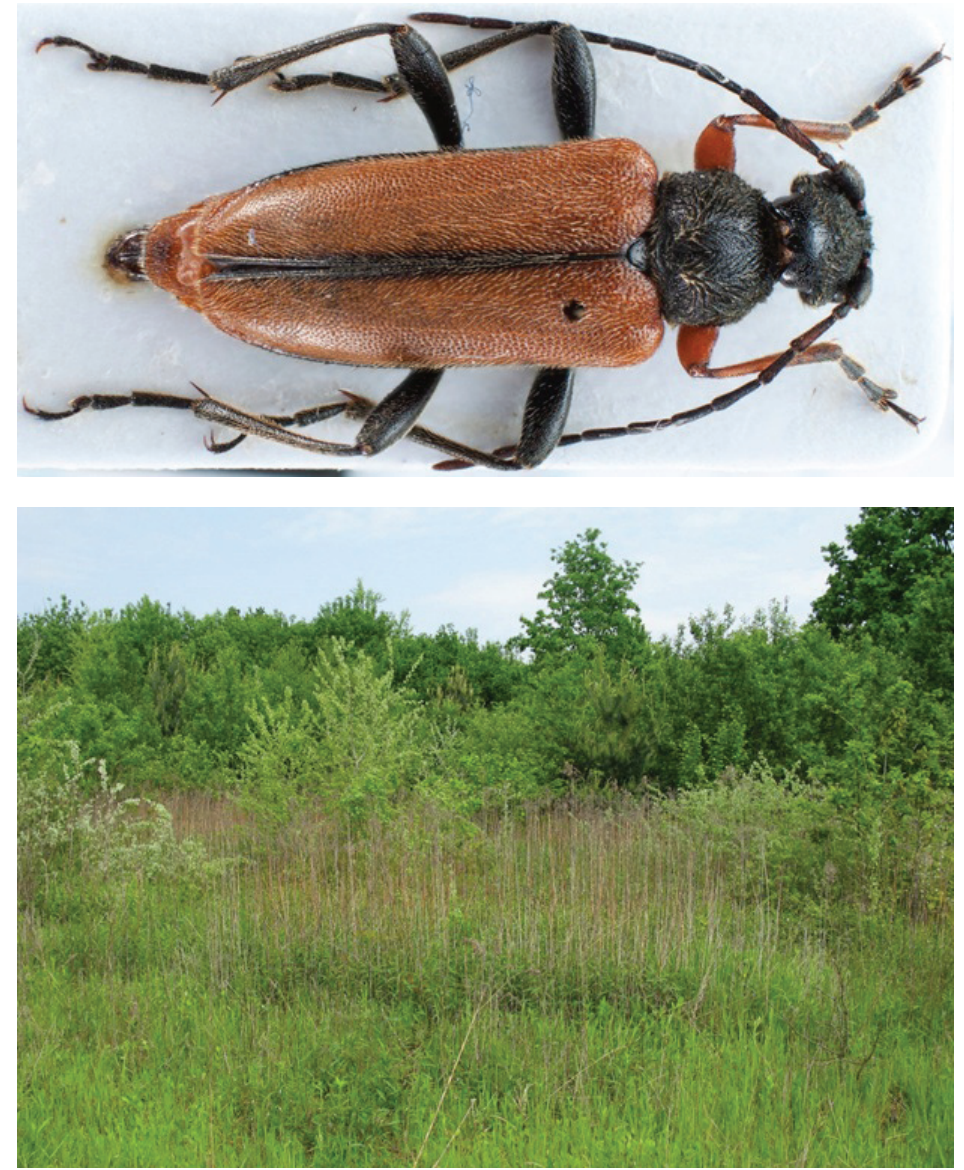

Fig. 2. Top: Cortodera flavimana from Okuje, south of Zagreb (Photo: Zoran Mandić). Bottom: habitat at Okuje, where the beetle was found. 
be expected. The species still has not been found in Slovenia, which is somewhat surprising, since it is present in all the neighbouring countries except Italy, and the cerambycid fauna of the country is well known (BRELIH et al., 2006).

\section{CONCLUSIONS}

Despite the numerous papers that have been published, we cannot really say that the Croatian longhorn beetle fauna is well-known. The many taxonomic changes, descriptions of new species in the Balkans (SAMA, 2002) and the new species recorded for the country have rendered the work of Miкšić \& GEORGIJEvić $(1971 ; 1973 ; 1985)$ fairly outdated. And since many longhorn beetle species are of economic importance and/or are threatened because of habitat loss/mismanagement, an updated review is needed (NIETO \& AlEXANDER, 2010), not just a review of the species list, but of the legislature concerning their protection. For instance, Croatia has only two „strictly protected" longhorn beetle species - Cerambyx cerdo Linnaeus, 1758 and Rosalia alpina (Linnaeus, 1758), while Morimus funereus Mulsant, 1862 is „protected” (Anonymous, 2009; 2013). To compare, Serbia, whose cerambycid fauna is the best known in the western Balkans, has seven "strictly protected" and 31 "protected" species, C. flavimana being among them (Anonymous, 2010). Future work should be focused on surveying the areas that have little or no or very old records, with the aim of producing a checklist and assessing the species for the Red Book of Croatian longhorn beetles.

\section{ACKNOWLEDGMENTS}

Our sincerest thanks go to Pierpaolo Rapuzzi, for confirming the identifications of our two specimens and to Zoran Mandić for photographing our specimen.

Received February 9, 2016

\section{REFERENCES}

Adlbauer, K., 2001: Cortodera flavimana (Waltl, 1838) - neu für Österreich (Coleoptera: Cerambycidae). Beiträge zur Entomofaunistik 2, 118-120.

ANONYMous, 2009: Pravilnik o proglašavanju divljih svojti zaštićenim i strogo zaštićenim [WWW Document]. URL http://narodne-novine.nn.hr/clanci/sluzbeni/2009_08_99_2569.html (accessed 10.14.2015).

Anonymous, 2010: Pravilnik o proglašenju i zaštiti strogo zaštićenih i zaštićenih divljih vrsta biljaka, životinja i gljiva. Službeni glasnik Republike Srbije 5 (URL http://www.pzzp.rs/sr/download-centar/ finish/14/58.html, accessed 14.10.2015)

Anonymous, 2013: Pravilnik o strogo zaštićenim vrstama [WWW Document]. URL http://narodne-novine.nn.hr/clanci/sluzbeni/2013_12_144_3086.html (accessed 14.10.2015).

BENSE, U., 1995: Bockkäfer : illustrierter Schlüssel zu den Cerambyciden und Vesperiden Europas = Longhorn beetles. Margraf Verlag, Weikersheim, 512 pp.

Brelih, S., Drovenik, B. \& Pirnat, A., 2006: „Gradivo za favno hroščev (Coleoptera) Slovenije = Material for the Beetle Fauna (Coleoptera) of Slovenia. 2. prispevek, $2^{\text {nd }}$ contribution, Polyphaga: Chrysomeloidea (= Phytophaga): Cerambycidae." Scopolia, 58, 1-442.

Demelt, C. v. \& Schurmann, P., 1964: Die Cerambycidenfauna von Istrien (Jugoslawien), Coleopte. Ceramb. Zeitschrift der Arbeitsgemeischaft Österreichischer Entomologien, 16, 26-43.

Demelt, C. v. \& Schurmann, P., 1966: 1. Nachtrag zur Cerambycidenfauna Istriens (Jugoslawien). Zeitschrift der Arbeitsgemeischaft Österreichischer Entomologien, 18, 70.

Demelt, C. v. \& Schurmann, P., 1973: 2. Nachtrag zur Cerambycidenfauna Istriens (Jugosl.). Zeitschrift der Arbeitsgemeischaft Österreichischer Entomologien, 24, 79.

Depoli, G., 1942: Revisione dei coleotteri della collezione Leoni Vi. Purpuricenus Kaehleri L. Bollettino dell'Instituto di Entomologia della R. Universit’a di Bologna XIII, Bologna, 178-202. 
de Jong, Y., Verbeek, M., Michelsen, V., Bjørn, P. de P., Los, W., Steeman, F., Bailly, N., Basire, C., Chylarecki, P., Stloukal, E., Hagedorn, G., Wetzel, F., Glöckler, F., Kroupa, A., Korb, G., Hoffmann, A., Häuser, C., Kohlbecker, A., Müller, A., Güntsch, A., Stoev, P., Penev, L., 2014. Fauna Europaea - all European animal species on the web. Biodiversity Data Journal 2, 1-35.

Łos, K. \& Plewa, R., 2011: Callidiellum rufipenne (Motschulsky, 1862) (Coleoptera: Cerambycidae) - new to the fauna of Croatia with remarks of its biology. Nature Journal, 44, 141-144.

ILIĆ, N. \& Ćurčıć, S., 2013: The longhorn beetles (Coleoptera: Cerambycidae) of Rtanj mountain: Serbia. Acta entomologica serbica, 18, 69-94

Koren, T., 2010: Longhorn beetles (Coleoptera: Cerambycidae) in central Istria. Entomologia Croatica, $14,77-84$.

Koren, T., Burić, I., Lauš, B., Rojko, I., Svoboda, P. \& Šerić Jelaska, L., 2010: Carabidae, Cerambycidae and Scarabaeoidea (Insecta: Coleoptera) fauna of Kornat, Lavsa and Žut islands, Croatia. Entomologia Croatica, 14, 53-62.

Koren, T. \& Perović, F., 2010: Contribution to the knowledge on the longhorn beetle (Coleoptera, Cerambycidae) fauna of Vozilići, Eastern Istria, Croatia. Annales Series Historia Naturalis, 20, 125-130.

Kovács, T., Németh, T. \& Merkl, O., 2012: Beetles new to Albania, Croatia and Serbia (Coleoptera: Elateridae, Cucujidae, Melandryidae, Cerambycidae). Folia Historico-Naturalia Musei Matraensis, 36, $43-44$.

Mıкšı́́, R., 1951: Daljnji prilog poznavanju vrste Purpuricenus budensis Goeze. Godišnjak Biološkog Instituta, 3, 259-262.

Мıкšı́, R., 1963. Prilog poznavanju faune strizibuba (Cerambycidae) Jugoslavije. Acta biologica 3, 55-188.

Mikšıć, R. \& Georgijević, E., 1971: Cerambycidae Jugoslavije. I. dio. Akademija nauka i umjetnosti Bosne i Hercegovine, Knjiga XLIII, Sarajevo.

Mıкšıć, R. \& Georgijević, E., 1973: Cerambycidae Jugoslavije. II. dio. Akademija nauka i umjetnosti Bosne i Hercegovine, Knjiga XLV, Sarajevo.

Mıкšıć, R. \& Georgijević, E., 1985: Cerambycidae Jugoslavije. III. dio. Akademija nauka i umjetnosti Bosne i Hercegovine, Knjiga LXII, Sarajevo.

MülleR, J., 1905: Die Rassen des Dorcadion arenarium Scop. Wiener Entomologische Zeitung XXIV, 129-153.

MüLler, J., 1906: Beiträge zur Kenntnis einiger Cerambyciden. Wiener Entomologische Zeitung, 25, 221-224.

MüLleR, J., 1906: Cerambycidae Dalmatiae. Verhandlungen der kaiserlich-königlichen zoologisch-botanischen Gesellschaft in Wien, 56, 653-695.

MüLleR, J., 1906: Über Dorcadion arenarium marsicanum D'Amore und subcarinatum m. Wiener Entomologische Zeitung, 25, 249-250.

Nieto, A. \& Alexander, K.N.A., 2010: European red list of saproxylic beetles. IUCN ; Publications Office of the European Union, Luxembourg.

NovaK, P., 1952: Kornjaši jadranskog primorja. Jugoslavenska akademija znanosti i umjetnosti, Zagreb.

NovaK, P., 1964: I coleotteri della Dalmazia. Atti del Museo Civico di Stona Naturale Treste.

NovaK, P., 1970: Rezultati istraživanja kornjaša našeg otočja, in: Acta Biologica VI, Prirodoslovna istraživanja. Jugoslavenska akademija znanosti i umjetnosti, Zagreb.

Özdikmen, H., 2003: The Genus Cortodera Mulsant, 1863 (Cerambycidae: Coleoptera) in Turkey. Phytoparasitica, 31, 433-441.

Rapuzzi, P., KonvičKa, O. \& Vít, D., 2011: The longhorn beetle Stenurella sennii (Coleoptera: Cerambycidae) in the Czech Republic and Croatia. Klapalekiana 47, 237-238.

SAMA, G., 2002: Northern, Western, Central and Eastern Europe, British Isles and continental Europe from France (excl. Corsica) to Scandinavia and Urals, Atlas of the Cerambycidae of Europe and the Mediterranean area. Kabourek, Zlín.

Vukadin, A., 2011: Azijska strizibuba - Anoplophora chinensis (Forster, 1771). Hrvatski centar za poljoprivredu, hranu i selo, Zavod za zaštitu bilja, Zagreb.

Vukadin, A. \& Hrašovec, B., 2008: Anoplophora chinensis (Forster) in Croatia. Forstschutz Aktuell, 44, 23-24.

Vukadin, A. \& Hrašovec, B., 2012: Citrus Longhorn Beetle Situation in Croatia - Two Years after the First Discovery. Forstschutz Aktuell 55, 38-39.

Vukajlović, F. \& Živanović, N., 2015: The longhorn beetles (Coleoptera: Cerambycidae) of the city of Kragujevac (Central Serbia). Kragujevac Journal of Science 37, 149-160, Kragujevac.

Wallin, H., Nylander, U. \& Kvamme, T., 2009: Two Sibling Species of Leiopus Audinet-Serville, 1835 (Coleoptera: Cerambycidae) from Europe: L. Nebulosus (Linnaeus, 1758) and L. Linnei Sp. Nov., Zootaxa, 2009, 31-45. 


\section{SAŽETAK \\ Prvi nalaz vrste Cortodera flavimana (Walt1, 1838) (Coleoptera: Cerambycidae) za Hrvatsku}

\section{Zadravec \& T. Koren}

Strizibube su uvijek plijenile pažnju i stručnjaka i amatera zbog svoje veličine i/ili primjetnosti. U zadnjih nekoliko desetljeća naše znanje o toj porodici uvelike je poraslo: utvrđena je distribucija mnogih vrsta, a objavljeno je i mnoštvo radova o njihovoj biologiji, razvoju ličinki i biljkama hraniteljicama (Bense, 1995; SAma, 2002). Također, mnoge vrste su od ekonomske važnosti i radi toga pobuđuju dodatno zanimanje stručnjaka i javnosti. Istraživanja ove porodice u Hrvatskoj, doduše sporadična, datiraju još s početka 20. stoljeća, no uglavnom su usmjerena na mediteranski dio države (Depoli, 1942; Müller, 1905, 1906a, 1906b, 1906c; Demelt \& Schurman, 1964, 1966, 1973; Koren, 2010; Koren et al., 2010; Koren \& Perović, 2010; MiKšić, 1951). Prvi konkretni pregled hrvatske faune, u sklopu Jugoslavije, je dan od strane Miкšića (1963) te Miкšića i Georgijevića (1971; 1973; 1985). Oni navode barem 225 vrsta za Hrvatsku, među njima četiri pripadnika roda Cortodera Mulsant, 1863. Pontijska vrsta Cortodera humeralis (Waltl, 1838) prisutna je i u jugoistočnoj Europi, a nađena je i u Austriji (Adrbauer, 2001). U Sloveniji nije zabilježena (Brelih i sur., 2010). Prilikom posjeta Cerni 2008. i Okuju 2013. godine (kontinentalna Hrvatska) sakupljen je po jedan primjerak. Time je ta vrsta prvi put zabilježena za Hrvatsku i predstavlja proširenje njenog poznatog područja rasprostranjenosti u Europi. Očekuju se novi nalazi s područja Hrvatske, barem u kontinentalnom dijelu. Potrebno je nastaviti s istraživanjima strizibuba u Hrvatskoj, s ciljem izrade novog popisa vrsta, te procijeniti njihovu ugroženost po IUCN kriterijima, radi izrade crvene knjige. 